ISSN 0258-7122 (Print), 2408-8293 (Online)

Bangladesh J. Agril. Res. 42(2): 373-378, June 2017

\title{
EFFICACY OF INSECTICIDES IN CONTROLLING POD BORER (HELICOVERPA ARMIGERA HUBNER) INFESTING CHICKPEA
}

\author{
MD. SHAHIDUZZAMAN ${ }^{1}$
}

\begin{abstract}
A field experiment was carried out at the Regional Pulses Research Station of Bangladesh Agricultural Research Institute, Madaripur, Bangladesh during rabi season of 2013-14 and 2014-15 to select effective insecticides to control pod borer (Helicoverpa armigera Hubner) of chickpea (Cicer arietinum). Signinificantly the highest insect infestation and yield loss were recorded from untreated control. Spray with every insecticide for 3 times at 7 days interval reduced insect infestation and yield loss significantly over control in both years. Reduction in insect infestation was $11.77-18.77 \%$ and $6.34-13.34 \%$ and yield loss was 280-393-168-281 $\mathrm{kgha}^{-1}$ in 2013-14 and 2014-15, respectively. The highest grain yield was obtained with Tracer 45 SC (Spinosad) (1177 $\mathrm{kgha}^{-1}$ ) followed by Volium Flexi $300 \mathrm{SC}$ (Thiamethaxam) (1045 kgha ${ }^{-1}$ ) and Belt $24 \mathrm{WG}$ (Flubendiamide) (1020 $\left.\mathrm{kgha}^{-1}\right)$ in first year. In second year, Tracer 45 SC produced maximum yield (1396 $\left.\mathrm{kgha}^{-1}\right)$ followed by Volium Flexi $300 \mathrm{SC}$ (1315 $\mathrm{kgha}^{-1}$ ) and Admire $200 \mathrm{SL}$ (Imidacloprid) (1300 kgha ${ }^{-1}$ ). In 2013-14, the highest benefit cost ratio (3.39) was obtained with Volium Flexi 300 SC followed by Belt 24 WG (2.65) and Admire 200 SL (1.67). In 2014-15, the highest benefit cost ratio was also obtained with Voilum Flexi 300 SC (2.38) followed by Admire 200 SL (1.79) and Belt 24 WG (1.63). Comparing two years data considering highest profit, Volium Flexi 300 SC might be applied @ $0.05 \%$ at an interval of 7 days to the crop for three times.
\end{abstract}

\section{Introduction}

Chickpea (Cicer arietinum L.), commonly known as gram is one of the important major pulse crops in Bangladesh. It is generally grown under rainfed condition in rabi season. Among the major pulses grown in Bangladesh, chickpea ranked 7th in terms of area and 6th in terms of production but second in terms of consumption. The national average yield of chickpea is only 1.09 tha $^{-1}$ (Anon., 2015). Among the factors responsible for low yield of the crop, insect pests appeared to be most important. The crop is attacked by eleven species of insect pests (Rahman et al., 1982). Among them pod borer, Helicoverpa armigera (Hubner) is major one of chickpea growing areas of the Bangladesh (Begum et al., 1992). Findings of a country wide survey indicate that 30 to $40 \%$ pods are damaged by pod borer causing $400 \mathrm{~kg}$ grain loss per hectare (Rahman, 1990). Under favourable conditions, pod borer may cause $90-95 \%$ pod damage (Shengal and Ujagir, 1990; Sachan and Katti, 1994). The young caterpillar feeds on

${ }^{1}$ Scientific Officer, Regional Pulses Research Station, Bangladesh Agricultural Research Institute (BARI), Madaripur, Bangladesh. 
leaves, while grown up caterpillar bores into the pods and feeds on the seeds. Pod borer damages flower, flower bud and developing pods (Hossain, 2012). The management of this noxious pest is primarily based on insecticides (Rahman, 1991). Under the above circumstances, the present piece of research was conducted to find out effective and suitable insecticides against pod borer infesting chickpea and to ensure economic production.

\section{Materials and Method}

Five insecticides, namely Admire 200 SL (Imidacloprid) (0.05\%), Belt 24 WG (Flubendiamide) $(0.04 \%)$, Tracer 45 SC (Spinosad) $(0.04 \%)$, Volium Flexi 300 SC (Thiamethaxam) $(0.05 \%)$ and Proclaim 5 SG (Emamectin Benzoate) $(0.1 \%)$ were tested against pod borer infesting chickpea under field conditions. Each of the insecticides represented a treatment. Plots received no spray with any insecticide represented untreated control. The experiment was conducted in the experimental farm of the Regional Pulses Research Station (RPRS) of Bangladesh Agricultural Research Institute, Madaripur, Bangladesh during the rabi season of 2013-14 and 2014-15. The land was prepared for good tilth using tractor driven cultivator and harrow. After ploughing, debris was removed from the field. NPK fertilizers were applied at final land preparation @ 20-40-20, respectively in the form of urea, triple super phosphate and muriate of potash, respectively. The experiment was laid out in Randomized Complete Block Design (RCBD) with three replications. The unit plot size was $3 \mathrm{~m} \times 4 \mathrm{~m}$. Seeds of a recommended variety BARI Chola-5 were sown in continuous rows maintaining $40 \mathrm{~cm}$ row to row spacing. The seedlings were thinned to have plant to plant distance of $10 \mathrm{~cm}$. Insecticidal suspensions were prepared in tap water and sprayed three times at 7 days interval starting from first appearance of the insects at flowering stage. Intercultural operations were done as and when necessary. Control plots were sprayed with tap water.

The experimental field was visited regularly to record infestation of the insect in treated and untreated control plots. For data collection, 10 plants were selected from middle rows of each unit plot at mature stage. The bored (damaged) and total number of pods found on selected plants was counted and percent pod infestation was computed based on total number of pods. After harvest and sunning, grain weight of each plot was recorded and expressed in yield per hectare. The grain yield loss per hectare due to pod borer infestation of each treatment was calculated using a standard formula based on percent pod infestation of actual yield obtained and expected yield in absence of any pod borer infestation for the respective treatment (Hossain et al., 1999). Yield loss of chickpea due to pod borer $=\mathrm{Ye}-\mathrm{Ya}$, where $\mathrm{Ya}=$ Actual yield $\left(\mathrm{kgha}^{-1}\right)$ and $\mathrm{Ye}=$ Expected yield in absence of any infestation.

$\mathrm{Ye}=\frac{\operatorname{YaX} 100}{100-P}$, where $\mathrm{P}=$ Percent pod infestation. 
Net return and benefit cost ratio were calculated by prevailing market price of the commodity. The experimental data were analyzed after arcsine and square root transformation in 2013-14 and 2014-15, respectively. The means were compared using DMRT.

\section{Results and Discussion}

\section{Pod borer infestation and yield loss}

Effectiveness of different insecticides tested in the present study to suppress pod borer infestation and yield loss of chickpea are presented in Table 1. All the insecticides significantly reduced insect infestation and yield loss compared to untreated control in both crop seasons.

In 2013-14, significantly the highest pod borer infestation of $39.89 \%$ and yield loss of $428 \mathrm{kgha}^{-1}$ were recorded from untreated control. The infestation was reduced to $25.12-28.12 \%$ and yield loss to $280-393 \mathrm{kgha}^{-1}$ due to spray with the insecticides. The highest reduction was achieved with Volium Flexi 300 SC and the lowest with Admire 200 SL.

In 2014-15, insect infestation was $24.67 \%$ and yield loss of $330 \mathrm{kgha}^{-1}$ recorded in untreated control plot. The two parameters were reduced to $11.33-18.33 \%$ and 168-282 $\mathrm{kgha}^{-1}$, respectively. The reduction was significant compared to untreated control. The lowest insect infestation and yield loss were recorded from plots sprayed with Volium Flexi 300 SC (Thiamethaxam) followed by Tracer 45 SC (Spinosad). The effectiveness of Volium Flexi 300 SC and Tracer 45 SC to reduce infestation was not significantly different. The highest insect infestation and yield loss were recorded in Proclaim 5SG treated plots.

Comparatively higher insect infestation was observed in 2013-14 compared to 2014-15. Such variation was due to higher rainfall recorded in 2013-14 which increased bushiness of chickpea plants and insect infestation. The rain fed cropping season of 2014-15 favored optimum growth of chickpea with higher pod setting and disfavor pod borer population increase. This was supported by (Hossain, 2003).

\section{Yield, net return and benefit cost ratio}

The Yield, net return and benefit cost ratio are presented in Table 2. The yield of chickpea varied significantly with crop growth, pod setting and pod borer infestation depending on climatic variation of the cropping seasons under study. As indicated earlier, the higher rainfall in 2013-14 cropping season resulted in the vigorous and bushy growth with less pod setting and also higher pod borer infestation in chickpea. In this season, the lowest yield $\left(645 \mathrm{kgha}^{-1}\right)$ was recorded from untreated control. The highest yield $\left(1177 \mathrm{kgha}^{-1}\right)$ was obtained from Tracer 45 SC treated plot followed by Volium Flexi 300 SC (Thiamethaxam) treated plot $\left(1045 \mathrm{kgha}^{-1}\right)$. Volium Flexi $300 \mathrm{SC}$ (Thiamethaxam) treated plot gave the 


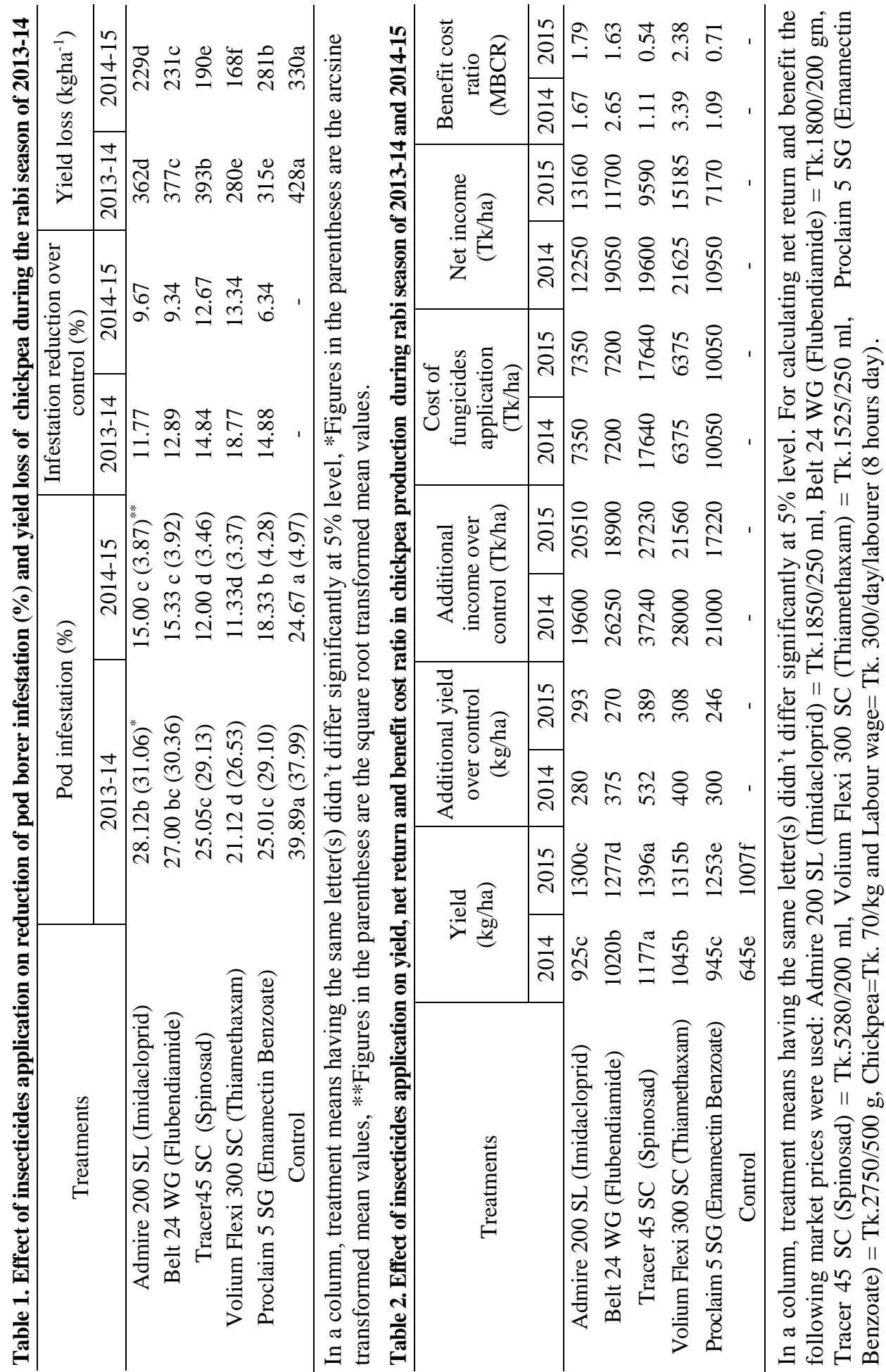


highest benefit cost ratio (3.39) followed by (2.65) Belt 24 WG (Flubendiamide) treated plots. The plots sprayed with Proclaim 5SG (Emamectin Benzoate) provided lowest benefit cost ratio (1.09).

In 2014-15, the yield performance of chickpea in the experimental plots was better than in 2013-14 crop seasons due to prevailing favorable climatic condition which favored higher pod setting but disfavored the pod borer infestation and population increase. The lowest yield $\left(1007 \mathrm{kgha}^{-1}\right)$ was recorded from untreated control plot. The highest yield $\left(1396 \mathrm{kgha}^{-1}\right)$ was obtained in Tracer 45 SC treated plot followed by $\left(1315 \mathrm{kgha}^{-1}\right)$ Volium Flexi 300 SC (Thiamethaxam). Volium Flexi 300 SC (Thiamethaxam) treated plots gave the highest benefit cost ratio (2.38) followed by (1.79) Admire 200 SL (Imidacloprid). The plot sprayed with Proclaim 5 SG (Emamectin Benzoate) gave benefit cost ratio less than one (0.71). The rest of the treatments had the same effects as in the previous year except Belt 24 WG (Flubendiamide). Chaudhary and Sachan (1995), on the other hand Hossain (2012) showed the significant effect of Cypermethrin application on pod borer population reduction compared to untreated control. Giraddi et al. (1994) reported effective control by Endosulfun when 2 sprays were applied at 50\% flowering followed by 2 sprays at the green pod stage (Hossain, 2012).

\section{Conclusion}

From the above discussion, it was found that, spraying of insecticides significantly reduced pod borer infestation in chickpea. Volium Flexi 300 SC (Thiamethaxam) treated plot resulted the lowest grain yield loss but highest yield obtained from Tracer 45 SC (Spinosad) treated plot in both the years. Due to higher price of this insecticide (Tracer $45 \mathrm{SC}$ ), BCR reduced than all other insecticides without Proclaim 5 SG. But Volium Flexi 300 SC (Thiamethaxam) offered the highest BCR in both the years. For getting highest profit, Volium Flexi 300 SC (Thiamethaxam) may be applied @ 0.05\% at an interval of 7 days for three times.

\section{References}

Anonymou. 2015. Acreage and Production of Pulse Crops, Krishi Diary, Agricultural Information Service. Department of Agricultural Extension. Peoples's Republic of Bangladesh. p.14

Begum, N., M. Hussain, and S. I. Chowdhury. 1992. Effect of sowing date and plant density of pod borer incidence and grain yield of Chickpea in Bangladesh. Int. Chickpea Newslet. 27: 19-21.

Chaudhary, R. R. P. and R. B. Sachan. 1995. Comparative efficacy and economics of some insecticides against gram pod borer, Heliothis armigera (Hubner) in chickpea in western plain of Uttor Pradesh. Bharatiya Krishi Anusandhan Patrika. 10(4): 159-164.

Giraddi, R. S., B. S. Goudreddy. and P. B. Patil. 1994. Critical time of spray in chickpea for the control of gram pod borer, Helicverpa armigera (Hubner). Karnataka J. Agril. Sci. 7(1): 79-81. 
Hossain, M. A. 2003. Management of chickpea pod borer, Helicoverpa armigera (Hubner) through intercropping and insecticide spraying. Thai j. Agric. Sci. 36(1): $51-56$

Hossain, M. A. 2012. Development of insecticide based management package against insect pests complex of chickpea. Annual Research Report under ACIAR Project, PRC, BARI, Ishwardi, Pabna.

Hossain, M. A., Rahman, M. M. and Islam, M. N. 1999. Effect of intercropping and sowing dates on the incidence of pod borer, Helicoverpa armigera, Yield and yield loss of chickpea. Ann. Bangladesh Agric. 9(1): 57-64.

Phokela, A., Dhingra, S. N. Sinha and K. N, Mehrotra. 1990. Pyrethroid resistance in Heliothis armigera $\mathrm{Hb}$. Development of resistance in field. Pesticide. Res. J. 2(1):28-30.

Rahman, M. M., M. A. Mannan and M. A. Islam. 1982. Pest survey of major summer and winter pulses in Bangladesh. In: Proceedings of the National Workshop on Pulses. August 18-19, 1981. Edited by A.K. Kaul. Published by Director, Bangladesh Agricultural Research Institute, Joydebpur, Dacca, Pp. 265-273.

Rahman, M.M. 1990. Infestation and yield loss in Chickpea due to pod borer in Bangladesh. Bangladesh J. Agril. Res. 15(2): 16-23.

Rahman, M.M. 1991. Control measures for important insect pests of major pulses. In BARI 1991. Advance in Pulse Research in Bangladesh. Procedings. Second National Workshop on Pulses, 6-8 Jan. 1989. Joydebpur, Gazipur, 139-146.

Sachan, J. N. and G. Katti. 1994. Integrated Pest Management. Proceeding of International Symposium on Pulses Research, April 2-6, IARI, New Delhi, India, Pp. 23-30.

Shengal, V.K. and R. Ujagir. 1990. Effect of synthetic pyrethroids, neem extracts and other insecticides for the control of pod damage by Helicoverpa armigera on Chickpea and pod damage-yield relationship at Patancheru in Northern India. Crop Protec. 9: 29-32. 